\title{
Ecological Inventory of Wetland Sites in the Thompson-Fisher Conservation Easement
}

Prepared for the

Montana Department of Fish, Wildlife \& Parks

Submitted by

W. Marc Jones and D. Paul Hendricks

May 2002

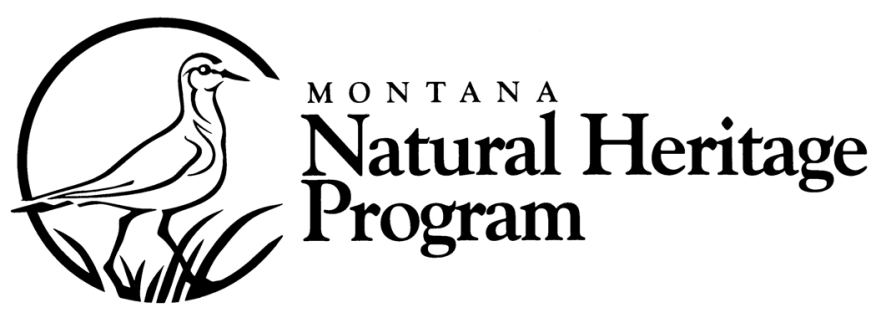




\section{Ecological Inventory of Wetland Sites in the Thompson-Fisher Conservation Easement}

May 2002

(C) 2002 Montana Natural Heritage Program

State Library Building, P.O. Box 201800, Helena, MT 59620-1800. 406-444-3009

This document should be cited as follows:

Jones, W. M., and D. P. Hendricks. 2002. Ecological inventory of wetland sites in the Thompson-Fisher conservation easement. Report to the Montana Department of Fish, Wildlife \& Parks. Montana Natural Heritage Program, Helena, MT. 


\section{INTRODUCTION}

The Montana Natural Heritage Program, in cooperation with the Montana Department of Fish, Wildlife \& Parks (FWP), has completed a survey of wetlands on Plum Creek Timber Company (PCTC) land in the Thompson and Fisher River drainages of northwestern Montana (Figure 1). This inventory documents the condition of wetland and riparian resources on a conservation easement that the Department is acquiring from PCTC and will help FWP identify wetlands of high ecological value.

\section{METHODS}

\section{Ecological Inventory}

We restricted our ecological inventory to higher quality wetlands on PCTC land within the current and proposed Thompson-Fisher conservation easement. Specifically, we sought wetlands with limited hydrologic and geomorphic modification that had intact, representative native plant communities. We also sought wetlands that supported rare species or plant communities or had outstanding wildlife habitat.

Wetlands were surveyed during the summer of 2001. Montana Natural Heritage Program ecologists used a standardized methodology based on Bourgeron et al. (1992) to assess site condition, catalog community types, and document rare plant and animal occurrences. Specifically, we attempted to walk through all wetland plant communities at any given site, except where prevented by deep water. For each dominant community, we collected species composition and coverage data from $400-\mathrm{m}^{2}, 200-\mathrm{m}^{2}$, or $50-\mathrm{m}^{2}$ relevé plots. Where applicable, we classified each wetland plant community using Hansen et al. (1995) and NatureServe (2002). The condition of each community was assessed using criteria such as the presence of exotic species, evidence of logging, hummocking or pugging, presence of ditches, dikes, riprap, and other geomorphic and hydrologic modifications. We also noted the depth of standing water and presence of beaver activity.

At each site, elevation, aspect, slope, and the hydrogeomorphic (HGM) class and subclass (Smith et al. 1995) were noted, as were the Cowardin system/subsystem, class/subclass, and hydrologic regime (Cowardin et al. 1979). We also recorded offsite land uses. A cursory search for rare plants was conducted during the walk-through of each wetland.

Sites were ranked using five factors: condition, landscape context, diversity, rarity, and size. Table 1 describes indicators for and the relative importance of these criteria. Each factor was rated A - D (numeric equivalents of $4-1$ ) and weighted as described in Table 1. An overall site rank of A-D was then calculated, where A was between 3.25 and 4.00, B was between 2.50 and 3.25, $\mathrm{C}$ was between 1.75 and 2.50 , and $\mathrm{D}$ was less than 1.75 . This system corresponds to the ranking strategy described in Greenlee and Jones (2000) as follows:

A = outstanding ecological significance

$\mathrm{B}=$ very high and high ecological significance

$\mathrm{C}=$ moderate ecological significance

$\mathrm{D}=$ not significant

\section{Plant Community Classification}

We defined plant associations based on the International Classification of Ecological Communities (NatureServe 2002). This database, developed by The Nature Conservancy and NatureServe, forms the basis for a standardized National Vegetation Classification. This classification is currently being developed by the Ecological Society of America, U.S. Geological Survey, and NatureServe, among others. It incorporates and expands on published state and regional plant community classifications, such as Pfister et al. (1977), Mueggler and Stewart (1980), and Hansen et al. (1995). 
Table 1. Indicators and relative importance of criteria used to rank the ecological and conservation significance of wetlands.

\begin{tabular}{|c|c|c|}
\hline Factor & $\begin{array}{c}\% \text { of } \\
\text { Overall } \\
\text { Rank }\end{array}$ & Indicators \\
\hline Condition & $25 \%$ & $\begin{array}{l}\text { - Alteration of geomorphic or biogeochemical processes. } \\
\text { - Presence of intact, representative native plant communities with characteristic } \\
\text { structure and composition. } \\
\text { - Presence of exotic species or cultural vegetation. }\end{array}$ \\
\hline $\begin{array}{l}\text { Landscape } \\
\text { Context }\end{array}$ & $25 \%$ & $\begin{array}{l}\text { - Alteration of hydrologic processes. } \\
\text { - Extent of land uses in the surrounding uplands that disrupt hydrologic and habitat } \\
\text { connectivity among the site, uplands, and adjacent wetlands. }\end{array}$ \\
\hline Diversity & $20 \%$ & $\begin{array}{l}\text { Number of plant communities, number of structural vegetation types, number of } \\
\text { hydrologic classes. }\end{array}$ \\
\hline Rarity & $20 \%$ & Number and condition of rare plants, animals, or plant communities present at the site. \\
\hline Size & $10 \%$ & Size of site. \\
\hline
\end{tabular}

Nomenclature

We used Hitchcock et al. (1955-1969) and Dorn (1984) to identify plant species in the study area. In keeping with International Classification of Ecological Communities (NatureServe 2002), we followed the nomenclature presented in Kartesz (1999) for vascular plants, except for Betula glandulosa (Bog Birch), where we used the Flora of North America (Furlow 1997). There are two other taxonomic considerations worth noting. The first concerns a common wetland sedge, often called Beaked Sedge, which has been erroneously called Carex rostrata in previous studies. While Carex rostrata does occur in northwestern Montana, it is very rare. In this report, we refer to Beaked Sedge as Carex utriculata (Griffiths 1989). Secondly, we use Picea engelmannii (Engelmann Spruce) to include Picea engelmannii, Picea glauca (White Spruce), and their hybrids (Daubenmire 1974). Table 2 presents the synonymy among Hitchcock and Cronquist (1973), Dorn (1984), and Kartesz (1999) for common and indicator species.

Table 2. Plant species synonymy.

\begin{tabular}{llll}
\hline Common Name & Hitchcock \& Cronquist (1973) & Dorn (1984) & Kartesz (1999) \\
\hline Black Cottonwood & Populus trichocarpa & Populus balsamifera & $\begin{array}{c}\text { Populus balsamifera } \text { ssp. } \\
\text { trichocarpa }\end{array}$ \\
Booth's Willow & Salix myrtillifolia & Salix boothii & Salix boothii \\
Red-Osier Dogwood & Cornus stolonifera & Cornus stolonifera & Cornus sericea \\
Arrowleaf Coltsfoot & Petasites sagittatus & Petasites sagittatus & Petasites frigidus var. \\
& & & sagittatus \\
American Cow-Parsnip & Heracleum lanatum & Heracleum sphondylium & Heracleum maximum \\
Beaked Sedge & Carex rostrata & Carex rostrata & Carex utriculata \\
Hardstem Bulrush & Scirpus acutus & Scirpus acutus & Schoenoplectus acutus \\
Marsh Cinquefoil & Potentilla palustris & Potentilla palustris & Comarum palustre \\
Mountain Sweet-Cicely & Osmorhiza chilensis & Osmorhiza chilensis & Osmorhiza berteroi \\
Slender Bog Orchid & Habenaria saccata & Habenaria saccata & Platanthera stricta \\
Spotted Knapweed & Centaurea maculosa & Centaurea maculosa & Centaurea biebersteinii \\
Starry False Solomon's Seal & Smilacina stellata & Smilacina stellata & Maianthemum stellatum \\
Streambank Ragwort & Senecio pseudaureus & Senecio pseudaureus & Packera pseudaurea \\
Western Dock & Rumex occidentalis & Rumex occidentalis & Rumex aquaticus \\
\hline
\end{tabular}




\section{Amphibian and Reptile Surveys}

Sites for amphibian surveys were identified through discussions with the Heritage Program wetland ecologist, Montana Fish, Wildlife \& Parks personnel, and study of USGS 7.5' topographic maps. Springs, marshes, small ponds, and valley-bottom sloughs were priority sites for surveys.

From 10-50 minutes were spent during each site survey (Table 4 in the Other Wetlands Surveyed section), depending upon areal extent of the site, site conditions (including weather), and what was found. Shorelines and wetland margins were searched for adults and juveniles while walking slowly along the edge; some sites were also scanned first for basking turtles with an 8-power binocular. The entire perimeter was searched at some sites; others were inspected by traversing the length of the site through shallow emergent vegetation. May searches included visual searches for egg masses attached to submerged and emergent vegetation. At regular intervals (where appropriate) the aquatic habitat was sampled for tadpoles or larvae using a dipnet. Time of day and duration of searches (a measure of search effort: Heyer et al. 1994, Olson et al. 1997), weather, and species encountered were recorded on standardized U.S. Fish and Wildlife Service data sheets. Most sites were visited more than once to increase possibility of detection and document phenology of development.

\section{RESULTS AND DISCUSSION}

\section{Ecological Inventory}

Six sites were identified as high quality wetlands. These include willow and sedge dominated bottomlands, remnant riparian spruce forest, and three peatlands. Site ranks for these sites are shown in Table 3. No "outstanding" wetlands were documented in the study area. This is in part due to the land use history of the region. Both the Thompson and Fisher River watersheds have been extensively logged, and the catchments of all wetlands surveyed had been at least partially clearcut. Although Plum Creek appeared to be following Best Management Practices and adhering to Streamside Management Zones, the logged-over nature of the uplands has likely altered the hydrology and biogeochemistry of surveyed wetlands to some degree. Another widespread consequence of timber harvesting in these watersheds is the abundance of exotic species, especially Phalaris arundinacea (Reed Canarygrass) in the floodplain of the Thompson and Fisher Rivers. Site locations are shown in Figures 2 and 3; see the Site Description section for detailed accounts of these wetlands.

Table 3. Site ranks for ecologically significant wetlands in the Thompson and Fisher watersheds.

\begin{tabular}{|c|c|c|c|c|c|c|}
\hline \multirow{3}{*}{ Weight factor $=$} & \multicolumn{6}{|c|}{ Site Rank } \\
\hline & 0.25 & 0.25 & 0.20 & 0.20 & 0.10 & $(1.00)$ \\
\hline & Condition & $\begin{array}{c}\text { Landscape } \\
\text { Context }\end{array}$ & Diversity & Rarity & Size & $\begin{array}{c}\text { Overall } \\
\text { Rank }\end{array}$ \\
\hline Upper Doe Creek & $\mathrm{A}$ & B & $\mathrm{D}$ & $\mathrm{B}$ & $\mathrm{C}$ & B \\
\hline Thompson R-Big Rock Ck & $\mathrm{A} / \mathrm{B}$ & B & B & $\mathrm{C}$ & B & B \\
\hline Lower Doe Creek & A & B & $\mathrm{C}$ & $\mathrm{D}$ & $\mathrm{C}$ & B \\
\hline Lost Lake Fen & $\mathrm{B} / \mathrm{C}$ & $\mathrm{C}$ & $\mathrm{C}$ & B & $\mathrm{C}$ & $\mathrm{C}$ \\
\hline Little Kettle & B & $\mathrm{C}$ & $\mathrm{D}$ & B & $\mathrm{C}$ & $\mathbf{C}$ \\
\hline Buck Creek & $\mathrm{C}$ & $\mathrm{C}$ & $\mathrm{C}$ & $\mathrm{D}$ & $\mathrm{C}$ & $\mathbf{C}$ \\
\hline
\end{tabular}

\section{Amphibian and Reptile Surveys}

We conducted nineteen site surveys for amphibians and reptiles at 10 sites in the Thompson River and Fisher River corridors (Table 4); all sites but one were visited once in May and once in August 2001. Three amphibian species (Long-toed Salamander Ambystoma macrodactylum, Pacific Tree Frog Hyla regilla, Columbia Spotted Frog Rana luteiventris) and two reptile species (Painted Turtle Chrysemys picta, Common Garter Snake Thamnophis sirtalis) were observed at nine of the survey sites. Columbia 
Spotted Frog was the species most often observed (eight sites, 10 site surveys), and was present in both river corridors. Long-toed Salamander was also present in both river corridors, but was observed at only three of the ten sites. Pacific Tree Frog, Painted Turtle, and Common Garter Snake were observed only in the Fisher River corridor at only one or two sites each.

We heard Pacific Tree Frogs calling in the evenings of 14 and 15 May at two additional locations in the Fisher River corridor; at least two in a small roadside marsh (T28N R29W, Sec. 13SWSW), and at least two in another roadside marsh opposite survey site \# 5 (T27N R29W Sec. 4NESE). An adult Painted Turtle was observed basking on 15 May at one additional location, in a small slough across the road from the Fisher River (T27N R29W, Sec. 9NWNE).

The amphibian and reptile species we detected during the wetland site surveys represent only a portion of the herpetofauna present in this part of Montana. Several species would not be expected to associate with wetland/aquatic habitats, but there are additional wetland species that we failed to observe that could be present. The Western Toad (Bufo boreas) probably is the amphibian species of greatest conservation interest that was not seen and which might reasonably be expected to associate with the wetlands along the Thompson River and Fisher River corridors. Western Toad was observed in small numbers during a wetland survey of the Thompson Chain of Lakes (Hendricks 2000) that occupy an area central to the wetland survey presented in this report. Either too few suitable sites were surveyed, or too few toads to detect remain in this altered landscape without an intensive survey effort. A combination of these two factors could also have contributed to our failure. Western Toad populations appear to be in decline throughout western Montana, with few breeding locations documented in recent years of intensive survey effort (Werner et al. 1998).

One amphibian species present nearby, the Inland Tailed Frog (Ascaphis montanus), inhabits swift mountain streams and would not be expected to occur in the wetland habitats surveyed. The same applies to the Coeur d'Alene Salamander (Plethodon idahoensis), which occupies fracture zones and seepages in northwestern Montana (Wilson et al. 1997) but whose habitat was not present in the two river bottoms.

Northern Leopard Frog (Rana pipiens), another amphibian of conservation interest in Montana, has been documented in northwestern Montana in past decades, from the Noxon area (1964) in Sanders County, and from Rogers Lake (1974) and near Marion on Bitterroot Creek (no date) in Flathead County, about 25 miles east of Thompson Chain of Lakes. However, there are no historical records from either the Thompson River or Fisher River corridors. The species was reported in June 2000 (without documentation) from the Thompson River bottom at our survey site \#3 (Table 4). We found Columbia Spotted Frog in August 2001 at the same site, but failed to find leopard frogs at any location. Northern Leopard Frog, like Western Toad, has experienced extirpation from many former sites in western Montana (Werner et al. 1998).

Few surveys for amphibians and reptiles have been conducted in our study areas that allow us to determine what species abundances and distributions may have been prior to or during intensive timber harvest of the river corridors and surrounding landscapes. At one location, the pond along McKillip Road (our site \# 4: Table 4), the two amphibian species we documented were observed at this same site in 1994 (Werner and Reichel 1994), suggesting that most of the amphibian species inhabiting the region in former years are still present in the landscape, and likely will reoccupy suitable wetland habitats once disturbance is removed. 


\section{SITE DESCRIPTIONS}

\section{Buck Creek}

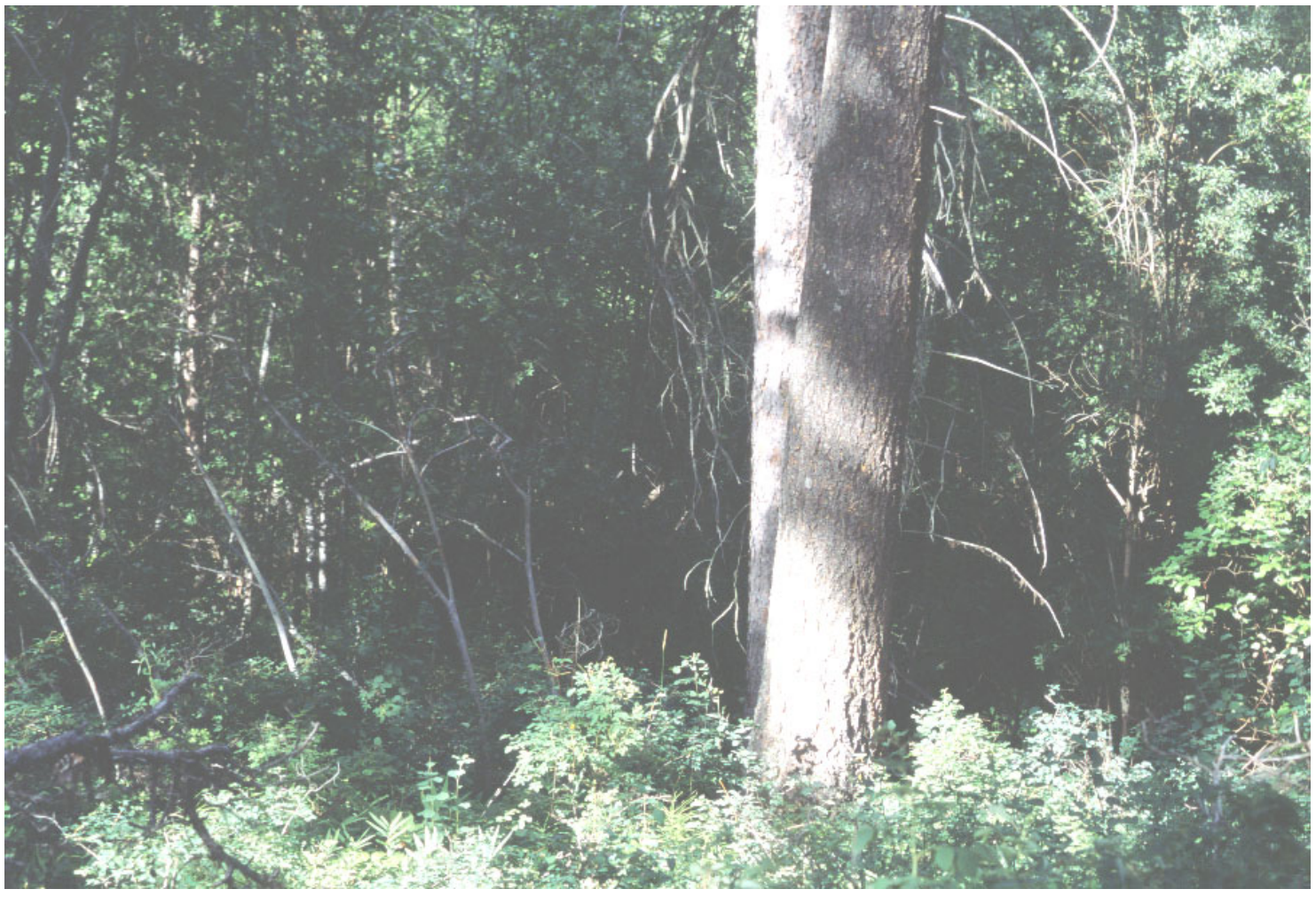

\section{Directions}

This site is located in the Fisher River watershed in northwest Montana. From Libby, travel east on State Route 37 for 14 miles. Turn south on the Fisher River Road and travel for about 4 miles to Forest Road 533. Travel west on this road for approximately 1 mile. The site lies to the south along Buck Creek.

\section{Description}

This riparian wetland occurs within a Streamside Management Zone along Buck Creek. An Alnus incana (Mountain Alder) community dominates the majority of the site. Tall shrubs, primarily Alnus incana and Betula occidentalis (Water Birch), form a dense, closed canopy over a well developed medium shrub layer of Symphoricarpos albus (Common Snowberry), Rubus idaeus (Red Raspberry), Lonicera involucrata (Twinberry Honeysuckle), Rosa acicularis (Prickly Rose), and Ribes sp. (Gooseberry). There is limited regeneration of Picea engelmannii (Engelmann Spruce), and there are a few, scattered Populus balsamifera ssp. trichocarpa (Black Cottonwood) trees present. There is a small remnant stand of mature Picea engelmannii on a small knoll within the floodplain. These trees are approximately 170 years old and have a diameter-at-breast-height $>20$ inches. They form a somewhat open canopy with a few smaller Pseudotsuga menziesii (Douglas-Fir). Amelanchier alnifolia (Western Serviceberry), Symphoricarpos albus (Common Snowberry), Rosa acicularis (Prickly Rose), Betula occidentalis (Water Birch), Alnus incana (Mountain Alder), Cornus sericea (Red-Osier Dogwood), and Mahonia repens (Creeping OregonGrape) dominate a well developed shrub layer. The abundant ground layer is dominated by Maianthemum stellatum (Starry False Solomon's-Seal), Aralia nudicaulis (Wild Sarsaparilla), Elymus 
virginicus (Virginia Wild Rye), and Equisetum arvense (Field Horsetail). Cirsium arvense (Canada Thistle) have colonized open areas in this site.

\section{Key Environmental Factors}

Fluvial processes, such as seasonal flooding and high groundwater, are the primary influence on the site's vegetation.

\section{Rarity}

No rare plants, animals, or plant communities were observed.

\section{Land Use}

Historically, this site was probably dominated by riparian Picea engelmannii (Engelmann Spruce) and Populus balsamifera ssp. trichocarpa (Black Cottonwood) forest. Past logging appear to have converted much of the site into an Alnus incana (Mountain Alder) community with limited Picea regeneration.

\section{Exotics}

Small, localized populations of Cirsium arvense (Canada Thistle) are present at the site.

\section{Uplands}

The uplands have been extensively logged.

\section{Information Needs}

How has timber harvesting in the catchment affected the site's functional capacity? Altered hydrology (increased inflows and peak runoff) and biogeochemical cycling (increased sedimentation and nutrient loading) are possible consequences of adjacent logging that may affect the vegetation and function of the site. Mechanical disturbance and overstory removal may also decrease the resilience of wetland edges to invasion by exotic species. Do 50-foot buffers adequately protect the site from these adverse effects?

\section{Management Needs}

Existing forest cover in excess of the 50-foot Streamside Management Zone buffer should be maintained.

\section{Element Occurrence Information}

\begin{tabular}{lcccc}
\hline & \multicolumn{2}{c}{ Rarity Ranks } & Viability & EO? \\
\cline { 2 - 3 } Plant Association / Dominance Type & State & Global & Rank & (Y/N) \\
\hline Picea engelmannii / Galium triflorum Woodland & S4 & G4 & C & N \\
Alnus incana Shrubland & S3 & G?Q & C & N \\
\hline
\end{tabular}




\section{Thompson River-Big Rock Creek}

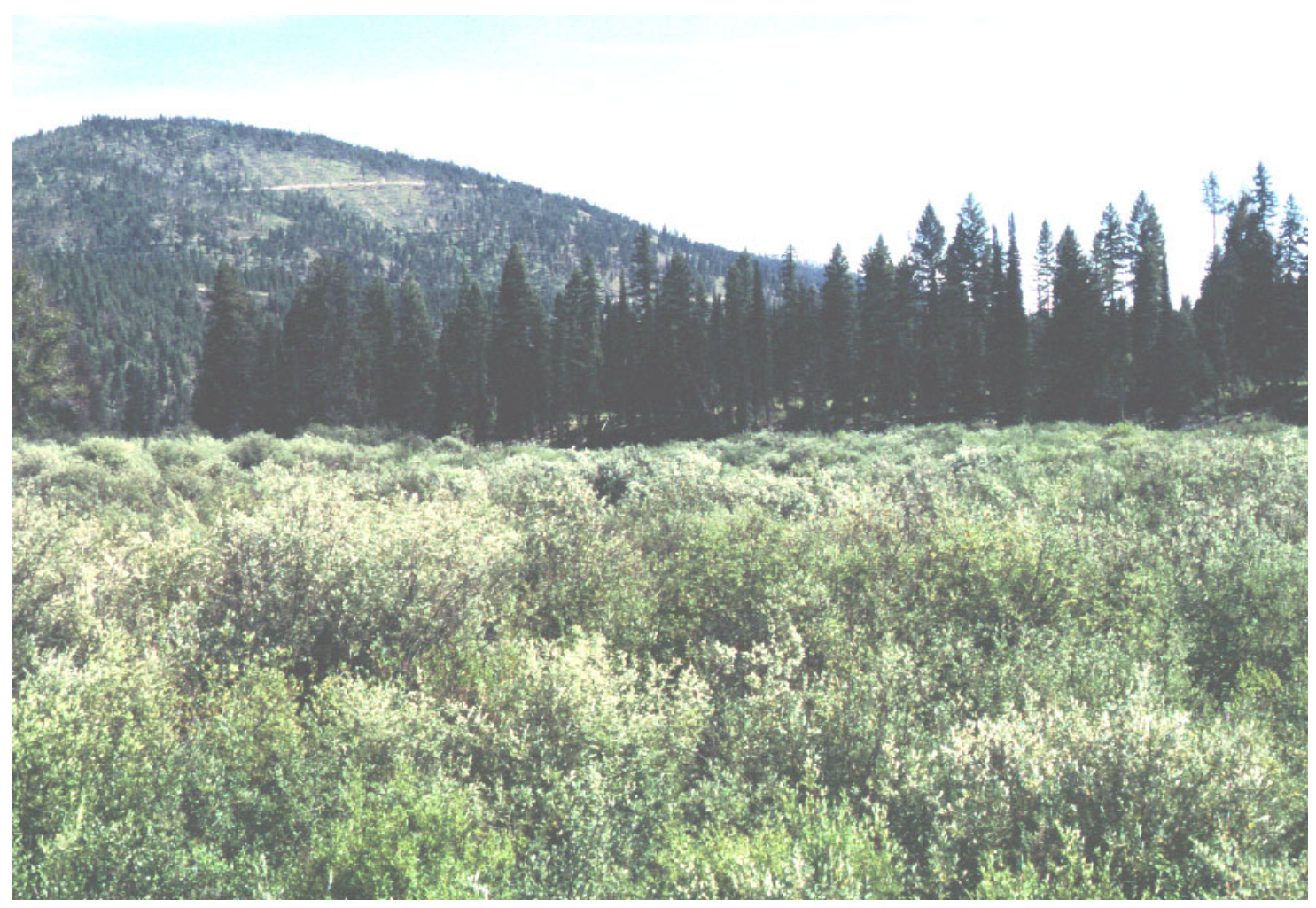

\section{Directions}

This site is located in the Thompson River watershed in northwest Montana. From Kalispell travel approximately 60 miles west on U.S. Highway 2. Turn south on Forest Road 56 (Thompson River Road) and travel for about 14.5 miles. The site is located at the confluence of the Thompson River and Big Rock Creek.

\section{Description}

This wetland is located in the floodplain of the Thompson River at its confluence with Big Rock Creek. In addition to high water tables associated with these streams, the site also receives groundwater from seeps that discharge from the adjacent toeslope. Most of this site is dominated by wet Salix drummondiana / Carex utriculata (Drummond's Willow / Beaked Sedge) and Carex utriculata communities. The willow community is co-dominated by tall Salix drummondiana and Salix geyeriana (Geyer's Willow) shrubs. Rhamnus alnifolia (Alderleaf Buckthorn), Salix boothii (Booth's Willow), and Cornus sericea (Red-Osier Dogwood) form a sparse low shrub layer. Carex utriculata dominates the ground layer; other common species present are Calamagrostis canadensis (Bluejoint Reedgrass), Scirpus microcarpus (Small-Fruit Bulrush), Comarum palustre (Marsh Cinquefoil), Geum macrophyllum (LargeLeaf Avens), Equisetum arvense (Field Horsetail), and Athyrium filix-femina (Lady Fern). Calamagrostis canadensis becomes the understory dominant on higher microsites. Lower areas are dominated by a near monospecific stand of Carex utriculata.

On higher ground adjacent to Big Rock Creek, vegetation is characterized by a Populus balsamifera ssp. trichocarpa / Symphoricarpos albus (Black Cottonwood / Common Snowberry) community. Mature (20inch diameter-at-breast-height) Populus balsamifera ssp. trichocarpa form a closed canopy with scattered 
mature individual Picea engelmannii (Engelmann Spruce) and Pinus ponderosa (Ponderosa Pine) present. Sapling-sized Picea engelmannii and Abies lasiocarpa (Subalpine Fir) occur at low cover. A dense layer of low Symphoricarpos albus dominates the shrub layer. Other common shrubs include Rosa woodsii (Woods' Rose), Alnus incana (Mountain Alder), Crataegus douglasii (Black Hawthorn), Amelanchier alnifolia (Western Serviceberry), and Cornus canadensis (Canada Bunchberry). The herbaceous layer is sparse; dominant species are Poa pratensis (Kentucky Bluegrass), Elymus glaucus (Blue Wild Rye), and numerous mesic forbs, including Geum macrophyllum (Large-Leaf Avens), Osmorhiza berteroi (Mountain Sweet-Cicely), Packera pseudaurea (Streambank Groundsel), and Senecio triangularis (Arrow-Leaf Ragwort).

\section{Key Environmental Factors}

This site is primarily influenced by high groundwater tables associated with the Thompson River and adjacent toeslope seeps that keep much of this site seasonally flooded. Beaver use was also noted at this site.

\section{Rarity}

No rare plants or animals were documented. One G2 and one G3 plant communities, Populus balsamifera ssp. trichocarpa / Symphoricarpos albus (Black Cottonwood / Common Snowberry) and Salix drummondiana / Calamagrostis canadensis (Drummond's Willow / Bluejoint Reedgrass), respectively, were documented in good condition.

\section{Land Use}

No human use was observed at most of this site. Some camping occurs along Big Rock Creek near the road.

\section{Exotics}

Exotic species are primarily restricted to drier portions of the site. These include Poa pratensis (Kentucky Blue Grass), Cirsium arvense (Canada Thistle), and Cynoglossum officinale (Hound'sTongue). Centaurea biebersteinii (Spotted Knapweed) is abundant on an adjacent toeslope. Phalaris arundinacea (Reed Canarygrass) forms monospecific stands in wet areas immediately adjacent to the Thompson River channel.

\section{Uplands}

Uplands have been extensively logged.

\section{Information Needs}

How has timber harvesting in the catchment affected the site's functional capacity? Altered hydrology (increased inflows and peak runoff) and biogeochemical cycling (increased sedimentation and nutrient loading) are possible consequences of adjacent logging that may affect the vegetation and function of the site. Mechanical disturbance and overstory removal may also decrease the resilience of wetland edges to invasion by exotic species. Do 50 -foot buffers adequately protect the site from these adverse effects?

\section{Management Needs}

The Phalaris arundinacea (Reed Canarygrass) population should be monitored. Upstream of this site, Phalaris has almost completely replaced native herbaceous species in the floodplain. This site may be at risk to a similar conversion, although the sedge-dominated herbaceous layer should be relatively resistant to invasion. 
Element Occurrence Information

\begin{tabular}{|c|c|c|c|c|}
\hline \multirow[b]{2}{*}{ Plant Association / Dominance Type } & \multicolumn{2}{|c|}{ Rarity Ranks } & \multirow{2}{*}{$\begin{array}{l}\text { Viability } \\
\text { Rank }\end{array}$} & \multirow{2}{*}{$\begin{array}{l}\text { EO? } \\
(\mathbf{Y} / \mathbf{N})\end{array}$} \\
\hline & State & Global & & \\
\hline Carex utriculata Herbaceous Vegetation & S5 & G5 & * & $\mathrm{N}$ \\
\hline $\begin{array}{l}\text { Populus balsamifera ssp. trichocarpa / Symphoricarpos albus } \\
\text { Forest }\end{array}$ & S? & G2? & $\mathrm{B}$ & Y \\
\hline Salix drummondiana / Calamagrostis canadensis Shrubland & S3 & G3 & $*$ & $\mathrm{~N}$ \\
\hline Salix drummondiana / Carex utriculata Shrubland & S4 & G4 & A & $\mathrm{Y}$ \\
\hline
\end{tabular}

* Rank not assigned 


\section{Little Kettle}

\section{Directions}

This site is located in the Fisher River watershed in northwest Montana. From Libby, travel east on State Route 37 for 14 miles. Turn south on the Fisher River Road and travel for a little over 13 miles to Forest Road 764. Travel west on this road for about 1.3 miles. Turn right onto an unnamed road and travel for approximately 3 miles. Veer left and travel up a spur road for 0.3 mile to the site.

\section{Description}

This small kettle depression is a peatland dominated by a Carex utriculata (Beaked Sedge) community. Equisetum fluviatile (Water Horsetail), Comarum palustre (Marsh Cinquefoil), and Typha latifolia (Broadleaf Cattail) are present at low cover. Equisetum fluviatile becomes more abundant on the peatland margins where it becomes co-dominant to dominant in places. A soil pit revealed over $40 \mathrm{~cm}$ of peat grading into mucky peat.

\section{Key Environmental Factors}

A stable hydrologic regime and saturated conditions have led to the development of peat soils and is the primary influence on the structure and composition of the wetland's plant communities.

\section{Rarity}

No rare plants, animals, or plant communities were documented at this wetland. However, this site has enough peat soil development to be classified as a peatland. This type of wetland is rare in Montana, and provides habitat for 40 species of rare vascular and non-vascular plants, one rare animal, and several rare plant communities.

\section{Land Use}

No land use was observed in the wetland.

\section{Exotics}

No exotic species were observed.

\section{Uplands}

The adjacent uplands have been extensively logged, and recent clearcuts abut the site. A Streamside Management Zone buffer was left around the wetland.

\section{Information Needs}

How has timber harvesting in the catchment affected the site's functional capacity? Altered hydrology (increased inflows and peak runoff) and biogeochemical cycling (increased sedimentation and nutrient loading) are possible consequences of adjacent logging that may affect the vegetation and function of the site. Mechanical disturbance and overstory removal may also decrease the resilience of wetland edges to invasion by exotic species. Do 50 -foot buffers adequately protect the site from these adverse effects?

\section{Management Needs}

A monitoring program that measured nutrient levels and plant species composition/diversity at this site and at nearby undisturbed peatlands could be used to evaluate the effectiveness of buffer strips.

\section{Element Occurrence Information}

\begin{tabular}{lcccc}
\hline & \multicolumn{2}{c}{ Rarity Ranks } & Viability & EO? \\
\cline { 2 - 3 } Plant Association / Dominance Type & State & Global & Rank & (Y/N) \\
\hline Carex utriculata Herbaceous Vegetation & S5 & G5 & B & N \\
\hline
\end{tabular}




\section{Lost Lake Fen}

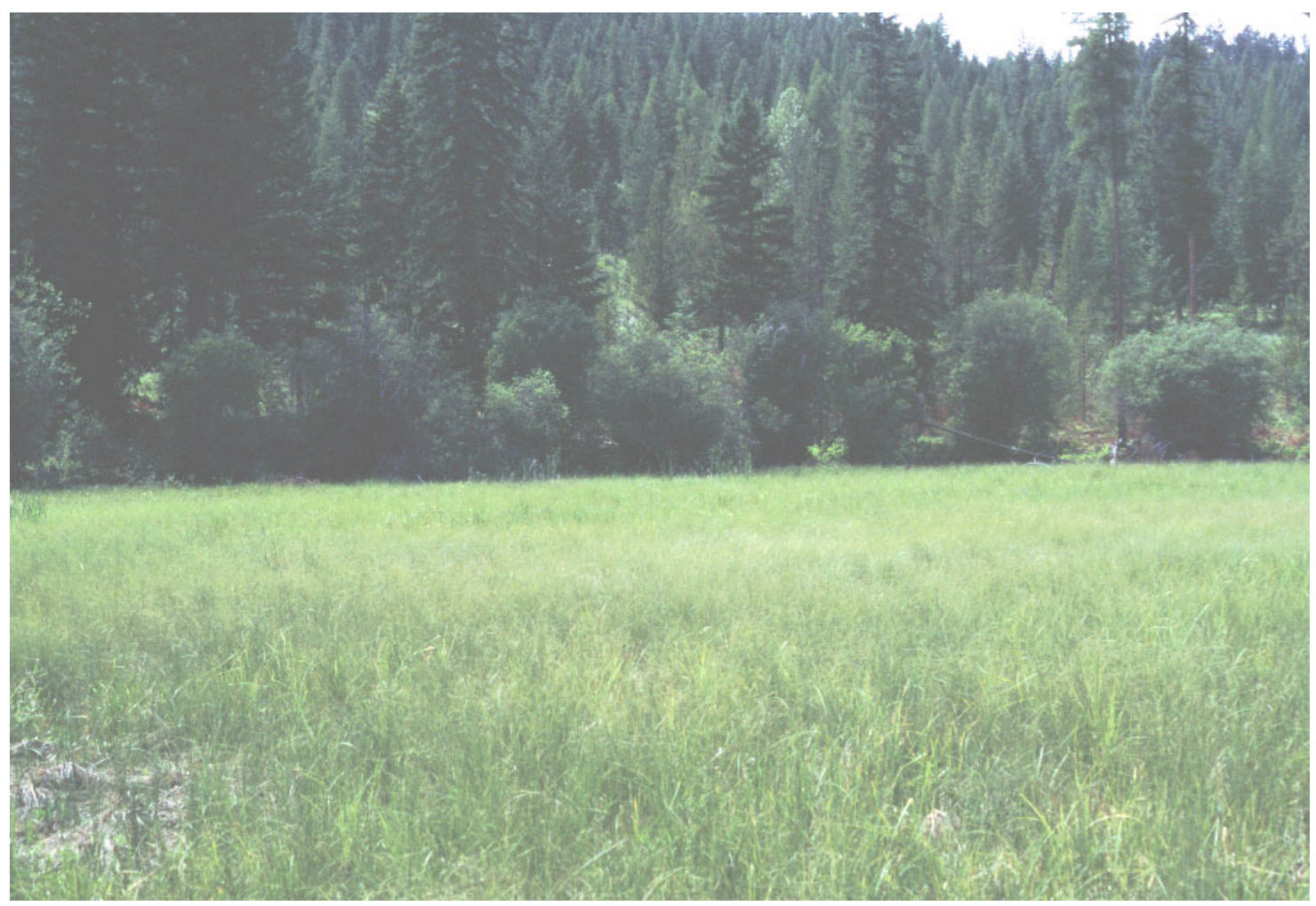

\section{Directions}

This site is located in the Fisher River watershed in northwest Montana. From Libby, travel east on State Route 37 for 14 miles. Turn south on the Fisher River Road and travel for about 7 miles to Forest Road 534. Travel west on this road for a little over 6 miles. A side road crosses Doe Creek and heads in a southerly direction. Travel on this road for approximately 1 mile until reaching Lost Lake. The fen is located above the lake immediately to the west.

\section{Description}

Lost Lake is a small (11.5-acre), shallow kettle lake with narrow lacustrine fringe wetlands. These wetlands support emergent and aquatic plant communities. Emergent communities are monospecific stands dominated by Carex atherodes (Awned Sedge) and Schoenoplectus acutus (Hardstem Bulrush). The aquatic community is dominated by Polygonum amphibium (Water Smartweed), Potamogeton praelongus (White-Stem Pondweed), and Potamogeton zosteriformis (Flat-Stem Pondweed). A small peatland is perched above the lake. This 2.5 -acre fen is dominated by a Carex lasiocarpa (Slender Sedge) community. Carex lasiocarpa is the dominant species; however, Carex utriculata (Beaked Sedge), Carex diandra (Lesser Panicled Sedge), Comarum palustre (Marsh Cinquefoil), and Rumex aquaticus (Western Dock) are present at low cover. Carex utriculata and Typha latifolia (Broadleaf Cattail) communities occur on the fringes of the fen.

\section{Key Environmental Factors}

A stable hydrologic regime and saturated conditions have led to the development of peat soils and is the primary influence on the structure and composition of the fen's plant communities. 


\section{Rarity}

No rare plants, animals, or plant communities were documented at this wetland. However, this site has enough peat soil development to be classified as a peatland. This type of wetland is rare in Montana, and provides habitat for 40 species of rare vascular and non-vascular plants, one rare animal, and several rare plant communities.

\section{Land Use}

There is some pugging around the edge of the fen. This may be from livestock use.

\section{Exotics}

No exotic species were noted at the site.

\section{Uplands}

The uplands have been extensively logged. It appears that Stream Management Zone practices were observed. A 50-foot buffer with some overstory component remaining was left around the wetlands.

\section{Information Needs}

How has timber harvesting in the catchment affected the site's functional capacity? Altered hydrology (increased inflows and peak runoff) and biogeochemical cycling (increased sedimentation and nutrient loading) are possible consequences of adjacent logging that may affect the vegetation and function of the site. Mechanical disturbance and overstory removal may also decrease the resilience of wetland edges to invasion by exotic species. Do 50-foot buffers adequately protect the site from these adverse effects?

\section{Management Needs}

A monitoring program that measured nutrient levels and plant species composition/diversity at this site and at nearby undisturbed peatlands could be used to evaluate the effectiveness of buffer strips.

\section{Element Occurrence Information}

\begin{tabular}{|c|c|c|c|c|}
\hline \multirow[b]{2}{*}{ Plant Association / Dominance Type } & \multicolumn{2}{|c|}{ Rarity Ranks } & \multirow{2}{*}{$\begin{array}{l}\text { Viability } \\
\text { Rank }\end{array}$} & \multirow{2}{*}{$\begin{array}{l}\text { EO? } \\
(\mathbf{Y} / \mathbf{N})\end{array}$} \\
\hline & State & Global & & \\
\hline Carex atherodes Herbaceous Vegetation & S3S5 & G3G5 & $*$ & $\mathrm{~N}$ \\
\hline Carex lasiocarpa Herbaceous Vegetation & $\mathrm{S} 4$ & G4? & $\mathrm{C}$ & $\mathrm{N}$ \\
\hline $\begin{array}{l}\text { Polygonum amphibium Permanently Flooded Herbaceous } \\
\text { Alliance }\end{array}$ & S? & G5 & $*$ & $\mathrm{~N}$ \\
\hline Schoenoplectus acutus Herbaceous Vegetation & S5 & G5 & $*$ & $\mathrm{~N}$ \\
\hline Typha latifolia Western Herbaceous Vegetation & S5 & G5 & $*$ & $\mathrm{~N}$ \\
\hline
\end{tabular}

* Rank not assigned 


\section{Lower Doe Creek}

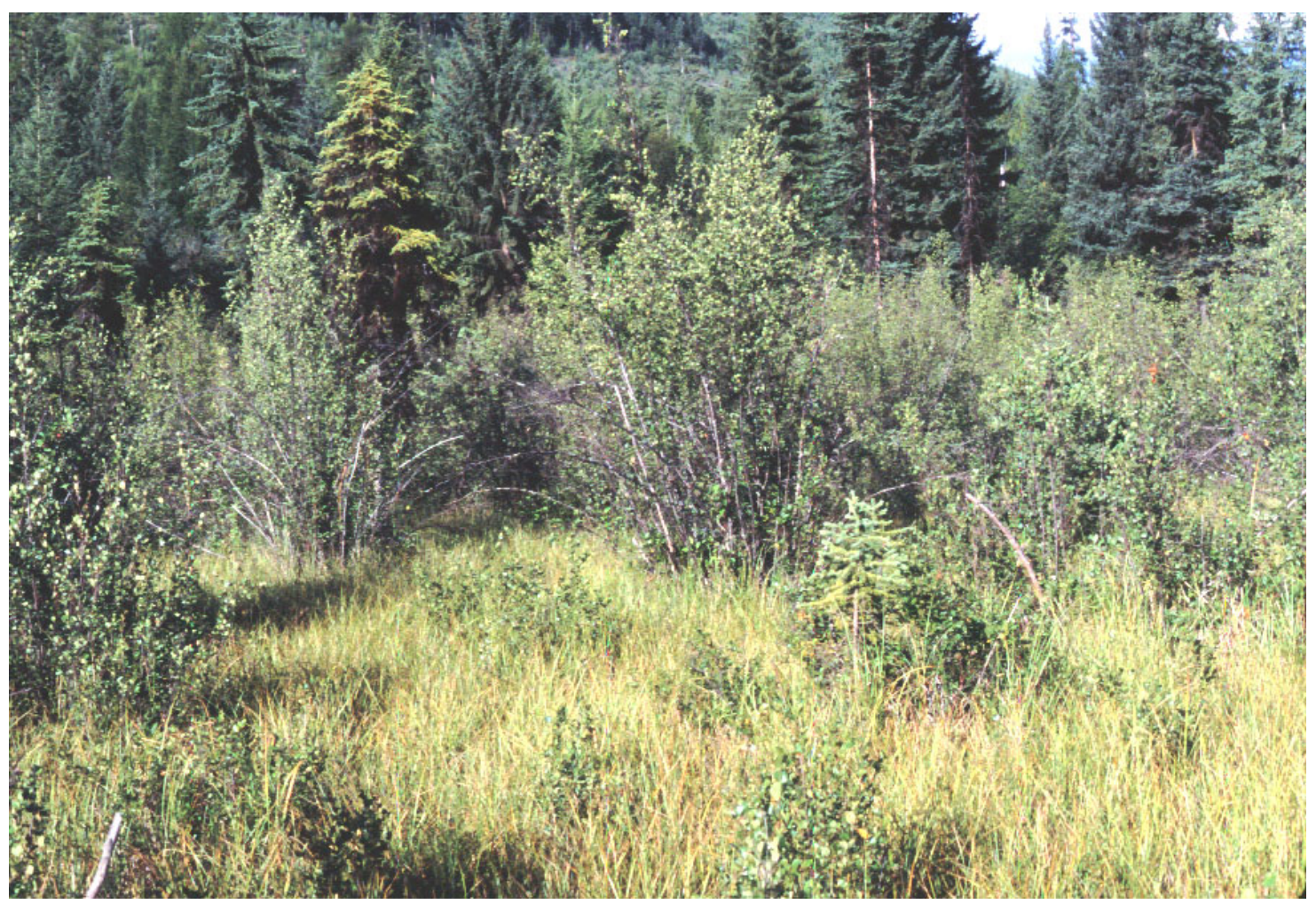

\section{Directions}

This site is located in the Fisher River watershed in northwest Montana. From Libby, travel east on State Route 37 for 14 miles. Turn south on the Fisher River Road and travel for about 7 miles to Forest Road 534. Travel west on this road for approximately 1.5 miles.

\section{Description}

This site is a small (2.5-acre) wetland with some peat development. Beaver activity has created several small ponds and raised water tables throughout the wetland. The majority of the site occurs on a slightly elevated flat with relatively little microtopography. Soils have high organic content. An open canopy Betula occidentalis (Water Birch) shrubland with a near-continuous Carex utriculata (Beaked Sedge) ground layer forms the dominant vegetation of this area. Other common species include Rhamnus alnifolia (Alderleaf Buckthorn), Cornus sericea (Red-Osier Dogwood), Salix bebbiana (Bebb Willow), Bromus ciliatus (Fringed Brome), Carex cusickii (Cusick's Sedge), and Viola sp. (Violet). Scattered sapling-size Picea engelmannii (Engelmann Spruce) and Pseudotsuga menziesii (Douglas-Fir) are also present. Wetter areas support small patches of Typha latifolia (Broadleaf Cattail) and Petasites frigidus var. sagittatus (Arrowleaf Colt's-Foot). A mature Picea engelmannii / Equisetum arvense (Engelmann Spruce / Field Horsetail) community occupies the Doe Creek floodplain upstream and downstream of the shrubland. This community supports numerous mesic forbs and has shrubby inclusions of Alnus incana (Mountain Alder). The uplands are second-growth Larix occidentalis (Western Larch)-Pseudotsuga menziesii forest.

\section{Key Environmental Factors}

These wetlands are influenced by past beaver activity and high water tables. 


\section{Rarity}

No rare plants, animals, or plant communities were observed.

\section{Land Use}

Some cow sign was observed, although there was little evidence of pugging or browsing. The wetland and adjacent floodplain forest was logged in the past.

\section{Exotics}

No exotic species were observed.

\section{Uplands}

The uplands were logged historically. The adjacent uplands have also been logged more recently, and large clearcuts abut the site. Forests immediately adjacent to the stream have not been recently cut.

\section{Information Needs}

How has timber harvesting in the catchment affected the site's functional capacity? Altered hydrology (increased inflows and peak runoff) and biogeochemical cycling (increased sedimentation and nutrient loading) are possible consequences of adjacent logging that may affect the vegetation and function of the site. Mechanical disturbance and overstory removal may also decrease the resilience of wetland edges to invasion by exotic species. Do 50 -foot buffers adequately protect the site from these adverse effects?

\section{Management Needs}

Existing forest cover in excess of the 50-foot Streamside Management Zone buffer should be maintained.

\section{Element Occurrence Information}

\begin{tabular}{lcccc}
\hline & \multicolumn{2}{c}{ Rarity Ranks } & Viability & EO? \\
\cline { 2 - 3 } Plant Association / Dominance Type & State & Global & Rank & (Y/N) \\
\hline Betula occidentalis / Carex utriculata Shrubland & $*$ & $*$ & $\mathrm{~A}$ & $\mathrm{Y}$ \\
Picea engelmannii / Equisetum arvense Forest & $\mathrm{S} 4$ & $\mathrm{G} 4$ & $*$ & $\mathrm{~N}$ \\
\hline
\end{tabular}

* Rank not assigned 


\section{Upper Doe Creek}

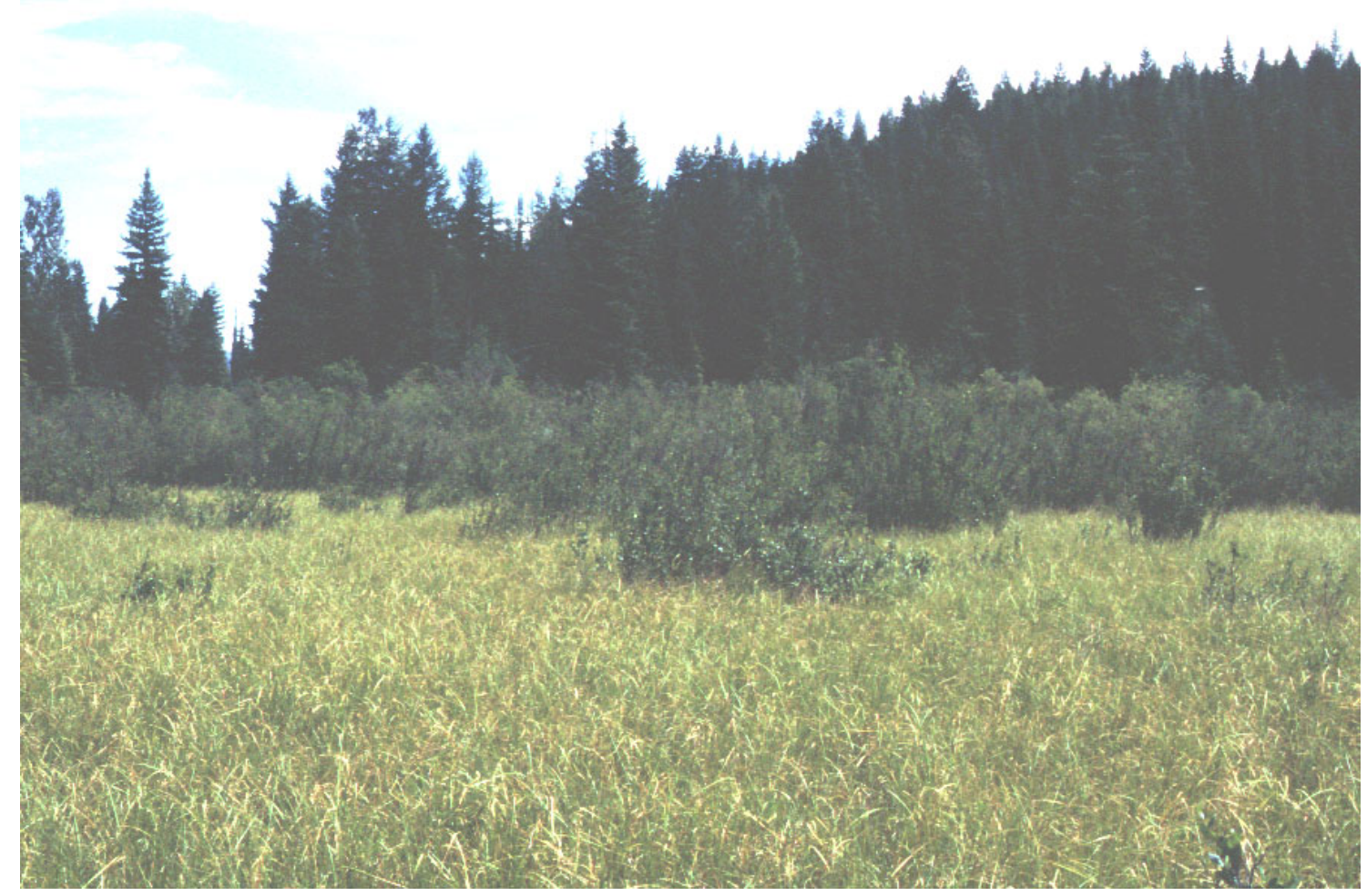

\section{Directions}

This site is located in the Fisher River watershed in northwest Montana. From Libby, travel east on State Route 37 for 14 miles. Turn south on the Fisher River Road and travel for about 7 miles to Forest Road 534. Travel west on this road for a little over 6 miles. The site is located along Doe Creek just upstream from where a side road continues on to Lost Lake.

\section{Description}

This wetland is a small peatland (approximately 4.2 acres) that occurs along Doe Creek. The site is underlain by peat soils to a depth of at least $43 \mathrm{~cm}$. There are also narrow $(2 \mathrm{~cm})$ lenses of silty loam in the soil profile. This site is dominated by Betula glandulosa / Carex utriculata (Bog Birch / Beaked Sedge) and Carex utriculata communities. Where it occurs, the Betula is clumped and ranges from 10 to 40 percent cover. Shrub cover is interspersed with many small openings dominated by Carex utriculata. Other common species documented in the Betula community include Rhamnus alnifolia (Alderleaf Buckthorn), Salix boothii (Booth's Willow), Salix drummondiana (Drummond's Willow), Bromus ciliata (Fringed Brome), Geum rivale (Purple Avens), Comarum palustre (Marsh Cinquefoil), and Platanthera stricta (Slender Bog Orchid). A few sapling-sized Picea engelmannii (Engelmann Spruce) are present throughout the wetland. Petasites frigidus var. sagittatus (Arrowleaf Colt's-Foot) is abundant in localized areas along the wetland edge.

\section{Key Environmental Factors}

A stable hydrologic regime and saturated conditions have led to the development of peat soils and is the primary influence on the structure and composition of the wetland's plant communities. 


\section{Rarity}

No rare plants, animals, or plant communities were documented at this wetland. However, this site has enough peat soil development to be classified as a peatland. This type of wetland is rare in Montana, and provides habitat for 40 species of rare vascular and non-vascular plants, one rare animal, and several rare plant communities.

\section{Land Use}

No land use was apparent at the site.

\section{Exotics}

No exotic species were noted at the site.

\section{Uplands}

The uplands have been extensively logged. It appears that Stream Management Zone practices were observed. A 50-foot buffer with some overstory component remaining was left along Doe Creek.

\section{Information Needs}

How has timber harvesting in the catchment affected the site's functional capacity? Altered hydrology (increased inflows and peak runoff) and biogeochemical cycling (increased sedimentation and nutrient loading) are possible consequences of adjacent logging that may affect the vegetation and function of the site. Mechanical disturbance and overstory removal may also decrease the resilience of wetland edges to invasion by exotic species. Do 50-foot buffers adequately protect the site from these adverse effects?

\section{Management Needs}

A monitoring program that measured nutrient levels and plant species composition/diversity at this site and at nearby undisturbed peatlands could be used to evaluate the effectiveness of buffer strips.

\section{Element Occurrence Information}

\begin{tabular}{lcccc}
\hline & \multicolumn{2}{c}{ Rarity Ranks } & Viability & EO? \\
\cline { 2 - 3 } Plant Association / Dominance Type & State & Global & Rank & (Y/N) \\
\hline Betula glandulosa / Carex utriculata Shrubland & $\mathrm{S} 4$ & $\mathrm{G} 4 ?$ & $\mathrm{~B}$ & $\mathrm{Y}$ \\
Carex utriculata Herbaceous Vegetation & $\mathrm{S} 5$ & $\mathrm{G} 5$ & $\mathrm{~B}$ & $\mathrm{~N}$ \\
\hline
\end{tabular}




\section{Other Wetlands Surveyed}

Amphibian and reptile survey sites are described in Table 4. Ecological survey areas that did not meet wetland site criteria are described below. Please refer to Figures 2 and 3 for the location of these areas.

Table 4. Amphibian and reptile species detected during wetland site surveys, May and August 2001 Thompson River-Fisher River inventory. Site numbers correspond to locations in Figure 1.

\begin{tabular}{|c|c|c|c|c|c|c|}
\hline $\begin{array}{l}\text { Site } \\
\text { No. }\end{array}$ & Site Name & TRS & Date & $\begin{array}{c}\text { Survey } \\
\text { Duration } \\
\text { (hr:min) }\end{array}$ & $\begin{array}{c}\text { Species }^{\mathrm{a}} \\
\text { (No. } \\
\text { individuals) }\end{array}$ & Comments \\
\hline 1 & Roadside seep & T23NR27W, S14NWSE & 14 Aug & $0: 10$ & RALU (5) & tadpoles \\
\hline 2 & Big Spring & T23NR27W, S23SWSW & 14 May & $0: 15$ & RALU (2) & adults \\
\hline “ & “" & “" & 14 Aug & $0: 15$ & RALU (2) & adults \\
\hline 3 & County Bridge & T24NR27W, S12NWNE & 16 May & $0: 30$ & AMMA (2) & egg masses \\
\hline “" & “ & “ & 14 Aug & $0: 50$ & RALU (3) & adults, juv \\
\hline 4 & $\begin{array}{l}\text { McKillip Road } \\
\text { Pond }\end{array}$ & T27NR28W, S6NWNW & 16 May & $0: 40$ & None & cold, rainy \\
\hline " & “ & “ & 15 Aug & $0: 25$ & $\begin{array}{l}\text { HYRE (10) } \\
\text { RALU (22) }\end{array}$ & $\begin{array}{l}\text { all juvs (3 } \\
\text { HYRE with } \\
\text { deformed limbs) }\end{array}$ \\
\hline 5 & Oxbow marsh & T27NR29W, S4SENE & 15 May & $0: 45$ & RALU (9) & adult, juvs \\
\hline “" & “" & “ & $15 \mathrm{Aug}$ & -- & None & mostly dry \\
\hline 6 & Roadside pond & T27NR29W, S8SENE & 15 May & $0: 30$ & $\begin{array}{l}\text { RALU (1) } \\
\text { CHPI (3) }\end{array}$ & $\begin{array}{l}\text { juv } \\
\text { adults }\end{array}$ \\
\hline “ & “ & “ & 15 Aug & $0: 40$ & $\begin{array}{l}\text { RALU (3) } \\
\text { CHPI (2) }\end{array}$ & $\begin{array}{l}\text { juvs } \\
\text { adults }\end{array}$ \\
\hline 7 & Roadside slough & T28NR29W, S13SENW & 15 May & $0: 15$ & None & \\
\hline “ & “ & “ & $15 \mathrm{Aug}$ & -- & None & dry \\
\hline 8 & Roadside marsh & T28NR29W, S26SESW & 15 May & $0: 25$ & None & \\
\hline " & " & " & 15 Aug & $0: 20$ & $\begin{array}{l}\text { AMMA (2) } \\
\text { RALU (3) } \\
\text { THSI (1) }\end{array}$ & $\begin{array}{l}\text { larvae } \\
\text { adult, juvs } \\
\text { adult }\end{array}$ \\
\hline 9 & Old slough & T28NR29W, S34NENE & 15 May & $0: 45$ & $\begin{array}{l}\text { AMMA } \\
(112+)\end{array}$ & larvae \\
\hline “" & “ & “ & 15 Aug & -- & None & dry \\
\hline 10 & Fawn Creek Marsh & T29NR29W, S22NWNW & 15 May & $0: 20$ & None & \\
\hline “ & " & 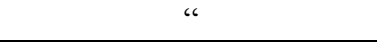 & 16 Aug & $0: 25$ & RALU (4) & juvs \\
\hline
\end{tabular}

a AMMA (Ambystoma macrodactylum: Long-toed Salamander), HYRE (Hyla regilla: Pacific Tree Frog), RALU (Rana luteiventris: Columbia Spotted Frog), CHPI (Chrysemys picta: Painted Turtle), THSI (Thamnophis sirtalis: Common Garter Snake).

\section{FR1 (Fawn Creek) = Herp Site \#10}

This area consists of sloughs associated with Fawn Creek and the Fisher River. The Fisher River Road has altered the hydrology of these wetlands by cutting them off from the Fisher River. These wetlands consist primarily of mesic herbaceous areas are dominated by Phalaris arundinacea (Reed Canarygrass), Poa palustris (Fowl Bluegrass), Agrostis stolonifera (Redtop), and Carex utriculata (Beaked Sedge). Herbaceous areas are fringed by small willow communities, primarily Salix bebbiana (Bebb Willow) and Salix geyeriana (Geyer's Willow), with an understory dominated by Phalaris arundinacea and 
Calamagrostis canadensis (Bluejoint Reedgrass). Natural levees support small stands of Populus balsamifera ssp. trichocarpa (Black Cottonwood), including an extremely small (0.25-acre) example of a Populus balsamifera ssp. trichocarpa / Cornus sericea (Black Cottonwood / Red-Osier Dogwood) community. This stand contains very large cottonwoods ( $>40$-inch diameter-at-breast-height) with abundant cover Cornus sericea and no exotic species.

\section{FR2 and FR3 (Fisher River Floodplain)}

The Fisher River floodplain once supported extensive stands of mature Populus balsamifera ssp. trichocarpa and Picea engelmannii (Engelmann Spruce). These stands have for the most part been logged.

FR2 - This area of the floodplain is characterized by strips of mature cottonwood-spruce forest interspersed with cut over areas. The logged areas are dominated by Phalaris arundinacea. Forest remnants still support typical understory species, but it is likely that Phalaris arundinacea and Symphoricarpos albus will become increasingly dominant due to high light levels associated with forest edges.

FR3 - This area of the floodplain has been largely clearcut. Within the Streamside Management Zone along the Fisher River, individual mature spruce and cottonwood trees are still standing. These trees exceed 40 inches diameter-at-breast-height, and some spruce exceed 55 inches. This area is now dominated by Symphoricarpos albus and Phalaris arundinacea communities. Phalaris arundinacea is especially abundant along the channel. Other abundant exotic species include Cirsium arvense (Canada Thistle), Tanacetum vulgare (Common Tansy), and Hypericum perforatum (Common St. John's-Wort).

\section{FR4 (Fisher River Oxbow) = Herp Site \#6}

This is a remnant slough cutoff from the Fisher River by a road. A ponded area underlain by clay soils supports Eleocharis palustris (Common Spikerush) and Carex utriculata communities. Phalaris arundinacea is becoming dominant throughout this marsh. The middle of the oxbow is filled with colluvium from an eroding cliff. The Fisher River is entrenched at this location.

\section{TR1 (Thompson River Floodplain)}

This portion of the Thompson River floodplain is largely dominated by Phalaris arundinacea. Native herbaceous communities, such as Carex utriculata and Calamagrostis canadensis, have been almost completely displaced by Phalaris. Willow stands, co-dominated by Salix drummondiana (Drummond's Willow), Salix geyeriana, and Salix boothii (Booth's Willow), also have a ground layer largely dominated by Phalaris arundinacea, although Carex utriculata co-dominates in places.

Although previously logged, the adjacent terrace supports a small stand of Picea engelmannii / Equisetum arvense (Engelmann Spruce / Field Horsetail). Mature spruce (16-inch diameter-at-breast-height) form a closed canopy over a patchy tall shrub layer dominated by Cornus sericea and Alnus incana (Mountain Alder). The ground layer is dominated by Equisetum arvense, but also included numerous mesic forbs and grasses, such as Festuca subulata (Bearded Fescue), Actaea rubra (Red Baneberry), Heracleum maximum (American Cow-Parsnip), Circaea alpina (Small Enchanter's-Nightshade), Osmorhiza berteroi (Mountain Sweet-Cicely), and Galium triflorum (Fragrant Bedstraw).

\section{TR2 (Meadow Creek)}

Discontinuous patches of a Populus tremuloides / Cornus sericea (Quaking Aspen / Red-Osier Dogwood) community occur along Meadow Creek. A closed canopy of Populus tremuloides with a dense shrub layer dominated by Crataegus douglasii (Black Hawthorn), Cornus sericea, Amelanchier alnifolia (Western Serviceberry), and Symphoricarpos albus characterizes this community. The stream channel is incised and slumping in places. Exotic species, including Cirsium arvense (Canada Thistle) and 
Centaurea biebersteinii (Spotted Knapweed), are abundant in nearby open areas. The adjacent uplands have been logged.

\section{TR3 (Thompson River Floodplain)}

This area supports a 25-acre willow bottom. Dominant willows are Salix geyeriana, Salix boothii, and Salix drummondiana. Carex utriculata dominates the understory in hygric areas. Calamagrostis canadensis becomes dominant in mesic areas, although it has largely been displaced by exotic grasses, including Agrostis stolonifera, Poa palustris, and Poa pratensis (Kentucky Bluegrass). Phalaris arundinacea is the dominant species along the channel. This species may expand into the floodplain as it has in areas further to the north. Cirsium arvense is also abundant along the channel. Drier areas support patches of Cornus sericea and Symphoricarpos albus. The adjacent uplands have been logged.

\section{Literature Cited}

Bourgeron, P. S., R. L. DeValice, L. D. Engelking, G. Jones, and E. Muldavin. 1992. WHTF site and community survey manual, version 92B. Western Heritage Task Force, Boulder, CO.

Cowardin, L. M., V. Carter, F. C. Golet, and E. T. LaRoe. 1979. Classification of wetlands and deepwater habitats of the United States. FWS/OBS-79/31, U.S. Department of interior, Fish and Wildlife Service, Washington, D.C.

Daubenmire, R. 1974. Taxonomic and ecological relationships between Picea glauca and Picea engelmannii. Canadian Journal of Botany 52:1545-1560.

Dorn, R. D. 1984. Vascular plants of Montana. Mountain West Publishing, Cheyenne, WY.

Furlow, J. J. 1997. Betulaceae. Pages 507-538 in Flora of North America Editorial Committee. Flora of North America north of Mexico, volume 3, Magnoliophyta: Magnoliidae and Hamamelidae. Oxford University Press, New York.

Greenlee, J. T., and W. M. Jones. 2000. Ecological inventory of wetland sites in the Thompson Chain of Lakes and vicinity. Report to the Montana Department of Fish, Wildlife, and Parks, Montana Natural Heritage Program, Helena, MT.

Griffiths, G. C. D. 1989. The true Carex rostrata in Alberta. Alberta Naturalist 19:105-108.

Hansen, P. L., R. D. Pfister, K. Boggs, B. J. Cook, J. Joy, and D. K. Hinckley. 1995. Classification and management of Montana's riparian and wetland sites. Miscellaneous Publication No. 54, Montana Forest and Conservation Experiment Station, School of Forestry, The University of Montana, Missoula, MT.

Hendricks, P. 2000. Amphibian and reptile survey of the Thompson Chain of Lakes. A report to the Montana Department of Fish, Wildlife \& Parks. Montana Natural Heritage Program, Helena, MT.

Heyer, W. R., M. A. Donnelly, R. W. McDiarmid, L. C. Hayek, and M. S. Foster, editors. 1994. Measuring and monitoring biological diversity, standard methods for amphibians. Smithsonian Institution Press, Washington, D.C.

Hitchcock, C. L., and A. Cronquist. 1973. Flora of the Pacific Northwest. University of Washington Press, Seattle, WA.

Hitchcock, C. L., A. Cronquist, M. Ownbey, and J. W. Thompson. 1955, 1959, 1961, 1964, 1969. Vascular plants of the Pacific Northwest, 5 vols. University of Washington Press, Seattle, WA. 
Kartesz, J. T. 1999. A synonymized checklist and atlas with biological attributes for the vascular flora of the United States, Canada, and Greenland. In J. T. Kartesz and C. A. Meacham. Synthesis of the North American Flora, version 1.0. North Carolina Botanical Garden, Chapel Hill, NC.

Mueggler, W. F., and W. L. Stewart. 1980. Grassland and shrubland habitat types of western Montana. General Technical Report INT-GTR-66, U.S. Department of Agriculture, Forest Service, Intermountain Forest and Range Experiment Station, Ogden, UT.

NatureServe. 2002. International classification of ecological communities: terrestrial vegetation. Natural Heritage Central Databases, NatureServe, Arlington, VA.

Olson, D. H., W. P. Leonard, and W. B. Bury, editors. 1997. Sampling amphibians in lentic habitats. Northwest Fauna Number 4.

Pfister, R. D., B. L. Kovalchik, S. F. Arno, and R. C. Presby. 1977. Forest habitat types of Montana. General Technical Report INT-GTR-34, U.S. Department of Agriculture, Forest Service, Intermountain Forest and Range Experiment Station, Ogden, UT.

Smith, R. D., A. Amman, C. Bartoldus, and M. M. Brinson. 1995. An approach for assessing wetland functions using hydrogeomorphic classification, reference wetlands, and functional indices. Technical Report WRP-DE-9, U.S. Army Corps of Engineers, Waterways Experiment Station, Vicksburg, MS.

Werner, J. K., T. Plummer, and J. Weaselhead. 1998. Amphibians and reptiles of the Flathead Indian Reservation. Intermountain Journal of Sciences 4:33-49.

Werner, J. K., and J. D. Reichel. 1994. Amphibian and reptile survey of the Kootenai National Forest: 1994. Montana Natural Heritage Program, Helena, MT.

Wilson, A. G., Jr., E. M. Wilson, C. R. Groves, and R. L. Wallace. 1997. U.S. distribution of the Coeur d'Alene salamander (Plethodon idahoensis Slater and Slipp). Great Basin Naturalist 57:359-362. 
Figure 1. Thompson-Fisher Study Area

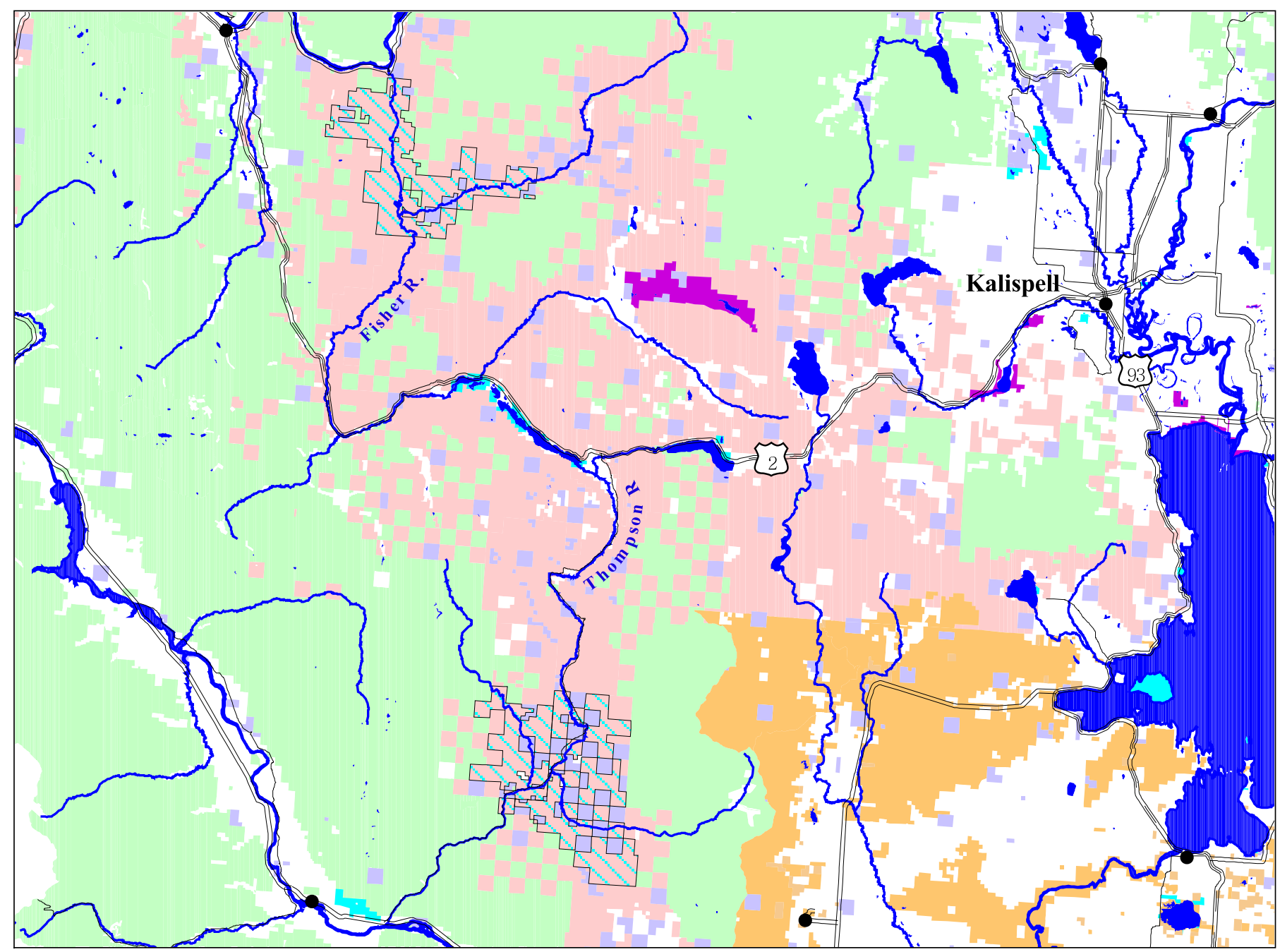

10 0 10 20 Miles

Existing Thompson-Fisher Conservation Easement Land Ownership

USFS

USFWS

BIA Trust

Tribal

State Trust

DFWP

Plum Creek

Other private

Water 
Figure 2. Fisher River Survey Areas

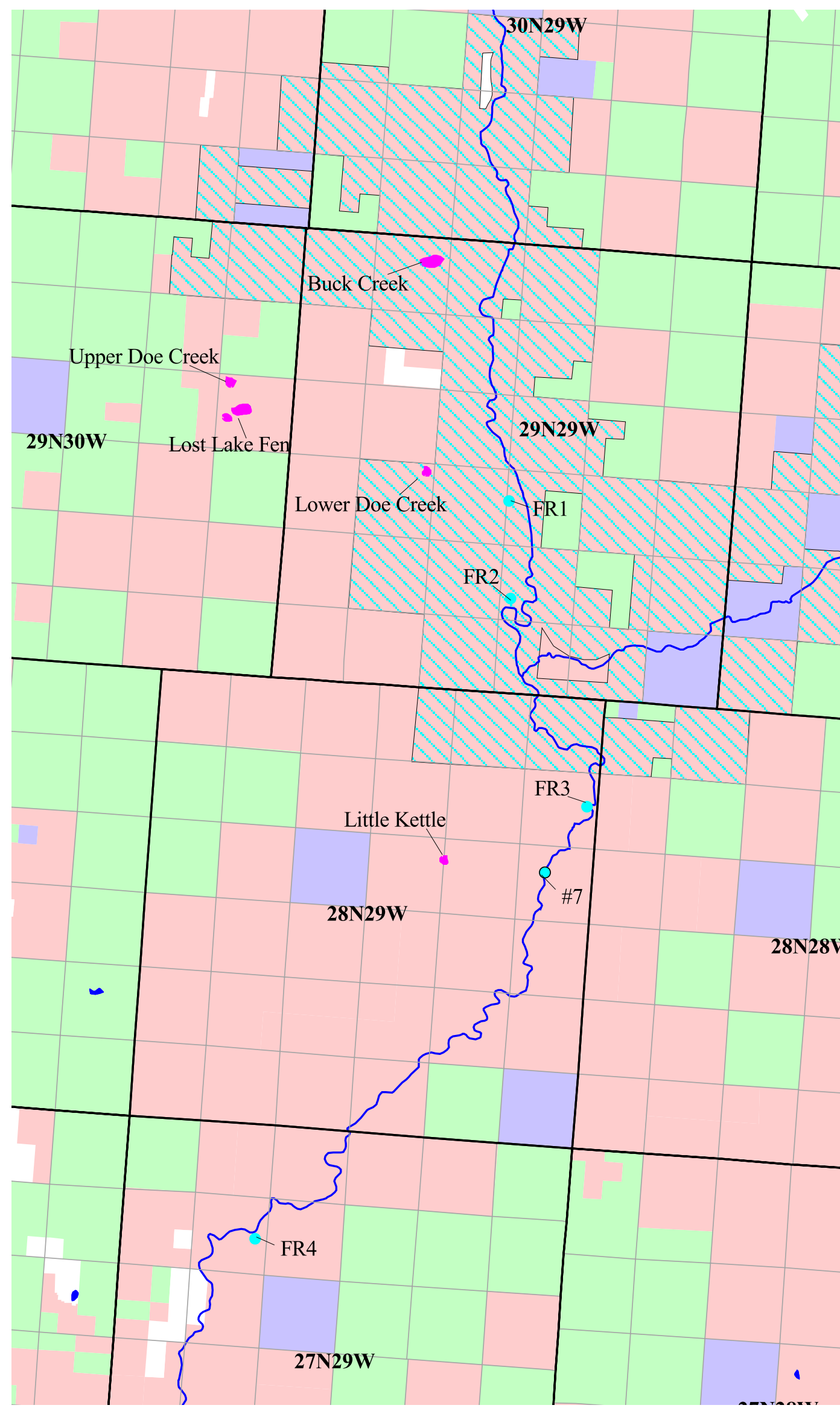

Ecologically Significant Wetlands

Other Ecological Survey Locations

Herptile Survey Locations

Existing FWP Conservation Easement

Land Ownership

USFS

State Trust

Plum Creek

Other private

Water

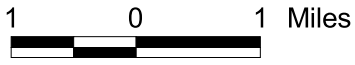


Figure 3. Thompson River Survey Areas

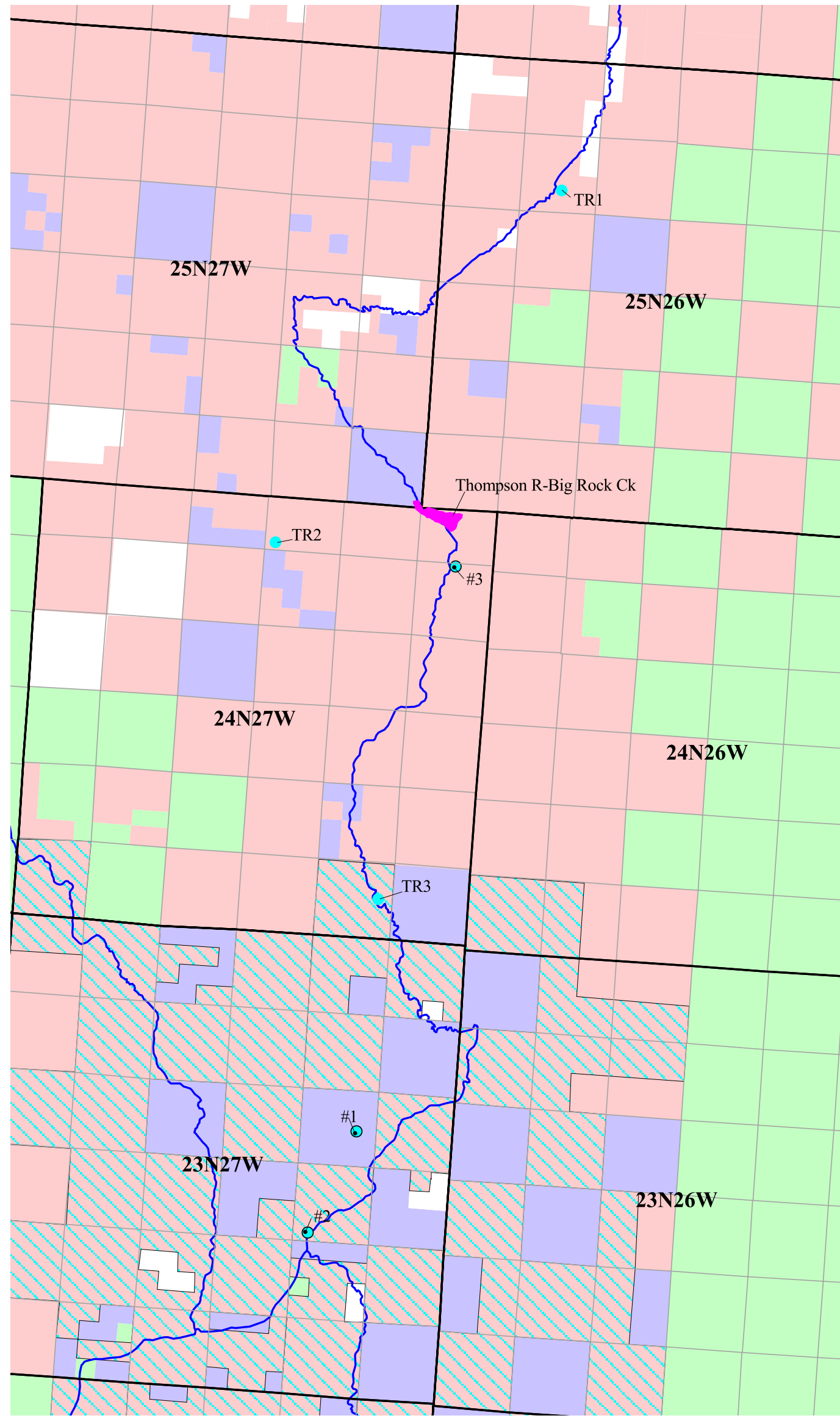

Ecologically Significant Wetlands

Other Ecological Survey Locations

O Herptile Survey Locations

Existing FWP Conservation Easement

Land Ownership

USFS

State Trust

Plum Creek

Other private

Water 